
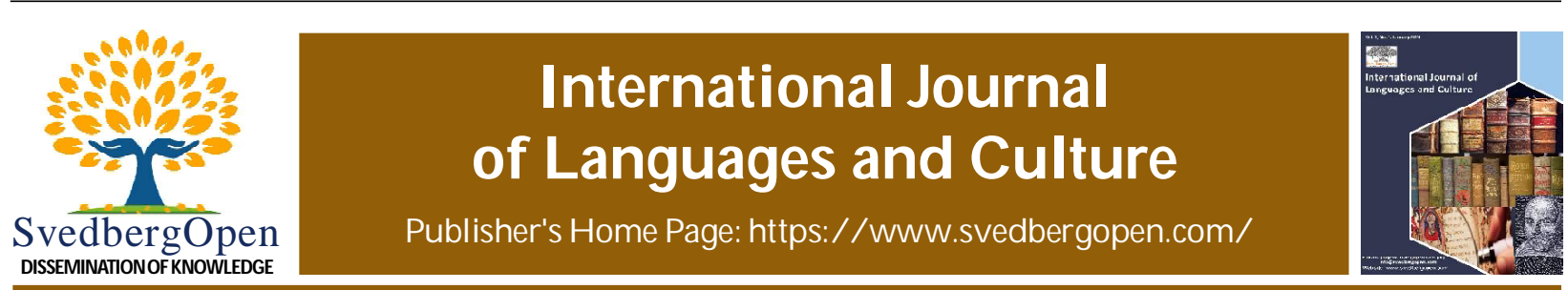

Research Paper

O pen A ccess

\title{
The value of family education in novel To Kill a Mockingbird: A hermeneutic study
}

\author{
Latifah Maurinta Wigati ${ }^{1 *}$ and H. Sofyan Sauri ${ }^{2}$ \\ ${ }^{1}$ Indonesian Education University, Bandung, Indonesia. E-mail: 1.maurinta.wigati@gmail.com \\ ${ }^{2}$ Indonesian Education University, Bandung, Indonesia. E-mail: sofyansauri@upi.edu
}

\section{Article Info}

Volume 1, Issue 2, June 2021

Received : 14 January 2021

Accepted : 19 May 2021

Published : 05 June 2021

doi: $10.51483 /$ IJLC.1.2.2021.8-13

\begin{abstract}
This study aims to interpret literary works from the point of view of hermeneutical, humanistic theory and their relation to the philosophy of science. Hermeneutic theory is used in various sciences. This theory is also used in interdisciplinary studies as a connection with interpretation and philosophy. The philosophy of science itself is a process of freedom to think in depth regarding information that is systematic, theoretical, and can be justified. The subject of this study is in the form of hermeneutic and humanistic theory and philosophy of science. The object of study is Harper Lee's novel To Kill A Mockingbird. This study is descriptive qualitative. Data were collected through reading and study methods (reading and reviewing). The form of data is in the form of writing/document. The quotations in the novel To Kill A Mockingbird which correspond to this study are interpreted with values in the Indonesian family from the writer's perspective as an Indonesian child. This study aims to interpret literary works from the point of view of hermeneutical, humanistic theory, and its relation to the philosophy of science. Hermeneutic theory is used in various sciences. This theory is also used in interdisciplinary studies as a reference for interpretation and philosophy. The philosophy of science itself is a process of thinking in depth regarding information that is systematic, theoretical, and can be justified.
\end{abstract}

Keywords: Hermeneutical theory, Humanistic theory, Interpretation, Phylosophy, Study methods.

(C) 2021 Latifah Maurinta Wigati and H. Sofyan Sauri. This is an open access article under the CC BY license (https://creativecommons.org/licenses/by/4.0/), which permits unrestricted use, distribution, and reproduction in any medium, provided you give appropriate credit to the original author(s) and the source, provide a link to the Creative Commons license, and indicate if changes were made.

\section{Introduction}

In writing literary works, writers have the freedom to express ideas. Readers also have the right to interpret the contents of the literary work according to applicable conventions. In his book, Text and Context and Context: An Introduction, Adrian Beard argues that literary books can influence readers to make good and bad choices in a moral action.

Interpretation is closely related to hermeneutic theory. It takes three stages to understand literary works: understanding, interpretation, and application in real life (Gadmer, 2008). There are times when a literary work reflects the author's self and the sociopolitical situation that occurred during the writing of the literary work. However, positive values that apply in a literary work are still valid in various eras.

A good literary work is not only entertaining, but also educational. One educational strategy that can be carried out in families or educators is through literature. The sooner the individual is introduced to literature, the faster the individual learns life.

* Corresponding author: Latifah Maurinta Wigati, Indonesian Education University, Bandung, , Indonesia. E-mail: l.maurinta.wigati@gmail.com 
According to Sofyan Sauri, education is a human effort to maintain its existence (humanizing humans). The definition of education in the narrow sense only focuses on the process of maturing humans through teaching and training. In a broad sense, education is obtained through students with themselves, the environment, culture, and all components that teach themselves. Education in a limited narrow sense includes adult relationships that educate younger people. Meanwhile, education in a broad sense involves various aspects between young people and the things that make them up.

Literary works include an educational component in a broad sense. Literary work is not in the form of a teacher teaching students. However, literary works educate a person through prose, poetry, words, sentences, paragraphs and phrases. The series that is integrated into a literary work is able to give a life value that remains in the reader.

Not all values of life can easily be absorbed into the reader's conscience. Therefore, understanding and interpretation are needed. A literary work can be interpreted from a point of view, depending on which perspective the reader sees it. That is the point of use of hermeneutic theory and philosophy of science as a rationale for interpreting literary works.

According to literary criticism, hermeneutics is needed to examine literary texts. Relevant hermeneutics is used to interpret literary works. Literary work, be it poetry or prose, requires interpretation / interpretation in its meaning. In fact, a literary work cannot be appreciated and enjoyed without going through a process of interpretation.

Literary and human works are inseparable poles. Humans create literary works, are delivered in language which is actually a means of human communication, and discuss human problems (although not all literary works purely discuss human issues). Literary work comes with all its complexity regarding problems in life. In addition to presenting problems in life, literary works raise values that can be applied in life. Attitudes, behavior, images, feelings, opinions and views of life are reflected in literary works.

The more often a person reads literature, the more subtle his feelings will be. Literary works carry social, religious, philosophical, cultural, etc. Herein lies hermeneutics in its role of interpreting literary works.

Novel as a form of literary work is a complex type of prose. The values it carries are more diverse, including the value of family education. The first education a person gets comes from the family (primary education). This study chooses Harper Lee's novel To Kill A Mockingbird as the object.

There are several things behind the novel To Kill A Mockingbird as an object of study. Reporting from the BBC, Harper Lee's To Kill A Mockingbird is a must-read for students in the United States. This beautifully written and inspirational work provides lessons on justice, equality and civic duty. This classic novel set in the 1930s is a guide to how to be a good parent. Previous research on Harper Lee's novel To Kill A Mockingbird, among others, is Tiolemba, in its description, researching the courage of the characters in Harper Lee's To Kill A Mockingbird. Monica (2019) analyzes moral values in Harper Lee's novel To Kill A Mockingbird. Norita examines the main character of Harper Lee's novel To Kill A Mockingbird.

Through this study, the following research questions can be drawn:

1. What does Harper Lee's novel To Kill A Mockingbird have to do with humanism, hermeneutics, and the value of family education?

2. How is Harper Lee's interpretation of the novel To Kill A Mockingbird hermeneutical?

3. How do family values compare in the novel To Kill A Mockingbird with Indonesian families from the point of view of children growing up in Indonesia?

\section{Theoretical Basis}

The values according to Sofyan Sauri are references and beliefs to make choices. The essence of values is in the form of norms, ethics, religion, laws, regulations, and customs. Values are abstract and produce output in the form of actions.

Family as the first agent in transferring the values of life to someone. Before someone enters a formal education level, they first receive education on values and norms from the family. In addition to educational values, norms, and ethics, family also gives someone the value of affection or affection.

Hermeneutics is described as a way to interpret something. If in everyday life hermeneutics can be used as a way to interpret a conversation, in literary works hermeneutics is used as an interpretation of the values in the work. Hermeneutics comes from Greek. Plato first used it to distinguish the characteristics of hermeneutics and sophia . Aristotle gave rise to the term hermeneutics in his work on logic and statements. Hermeneutics is used in interpreting the Gospels, starting with some Alexandrian researchers who used hermeneutics to examine the meaning of the Old Testament. Hermeneutics relates to the text, context, culture, and traditions that the readers of the text accept when interpreting it. In his argument, Schliermacher stated that hermeneutics aims to reconstruct the original context so that the words in the text can be understood properly. 
According to Wilhelm Dilthey, hermeneutics focuses more on understanding. Hermeneutics does not focus on explanation. That is why hermeneutics is more relevant in the study of human issues than in issues of natural science. Hermeneutics is designed to interpret something man-made.

Martin Heidegger made a major revolution in hermeneutic theory. Hermeneutics is no longer categorized into interpretations of texts and traditions as expressed by his colleagues, but is used as the basis for ontological understanding of human beings and their understanding of the world. The scope of hermeneutics is not only seen at the level of text, but has expanded in understanding life. So, it can be concluded that hermeneutics is a science that is useful for understanding / interpreting something.

James Bugental's five psychological postulates state the following:

1. Humans cannot be reduced to components.

2. Humans do not have a unique context in themselves.

3. Human consciousness really includes awareness of self in the context of others.

4. Humans are intentional, they seek meaning, value, and also have a lot of creativity.

5. Humans are intentional, they seek meaning, value, and also have a lot of creativity.

Abraham Maslow argues that the learning process in humans is a process by which it is to actualize itself. Arthur Combs stated that learning is something that can happen anywhere and at any time for someone who has meaning. The teacher cannot force someone to learn things that are disliked or considered irrelevant to them.

Humanistic learning theory is a way of learning to humanize humans. Humanistic cannot be separated from education. Education to produce something that is effective, learning that enhances creativity, and hones one's potential. Humanistic theory emerged as a resistance to behavioristic learning theory. Among the studies that study this theory is philosophy. Humanistic learning theory is more concerned with learning content than the learning process.

\section{Research methods}

This study is descriptive qualitative. The data collected is in the form of words and writings. Data collection was carried out using documentation techniques. Researchers recorded the passages in the novel To Kill A Mockingbird that are relevant to the theme of the study.

The data were collected by using the sampling method. The data is taken by sampling from a similar data set. After the data is collected, data presentation, analysis, and conclusions are drawn.

\section{Discussion}

Book title: To Kill A Mockingbird

Author: Harper Lee

Publisher: JB Lippincott \& Co. (United States), Qanita (Indonesia)

Year of publication: 1960

Number of pages: 296

\section{Synopsis}

This novel, set in 1936, was written based on the author's observations of his family and neighbors when he was 10 years old. The storyline in this novel is told by a little girl named Scout Finch. Scout a girl who prefers to play and dress like a boy. She and her older brother, Jeremy or Jem as they are called, spend most of their time together. Scout and Jem live with their father, Atticus Finch. Atticus is a lawyer.

The issues raised in this novel are quite serious. The moment of storytelling lies in one of the major cases Atticus handled. He defended a black Negro worker named Tom Robinson. Tom is accused of raping a white girl named Mayella Ewell. In fact, Tom didn't do that. Justice was not on his side because Tom was not white. He remains convicted. Tom died from being shot while trying to escape from prison. The Ewells had a grudge against Atticus. Mayella's father, Bob, tries to attack Jem. However, Jem is saved by Arthur Radley, a mysterious neighbor who never leaves his house.

\section{Sayings of love}

\section{Quote 1:}

Sometimes, when we took a midnight trip to the bathroom, we found him reading. He said he would often wake up at night, check on us, and read himself to sleep (To Kill A Mockingbird, 72). 
The quote shows Atticus Finch's concern for his two children without a word. At night, even though he is busy working as a lawyer, Atticus Finch still finds time to check on his kids in their room. Atticus Finch hardly ever verbally expressed his affection for Jem and Scout. The forms of attention are sufficient to describe affection. There are also parents in Indonesia who do this method. Although they don't express much affection verbally, parents in Indonesia will take action without words to pay attention to their children.

\section{Quote 2:}

After dinner Atticus sat down with a newspaper and called out, "Scout, ready to read?" (To Kill A Mockingbird, 34).

Each night Atticus took the Scout on his lap and read with him. The various books Atticus read to Scout, from newspapers and novels to the diaries that were kept. This habit makes Scout read fluently before entering school.

Habits like this are not familiar to parents in Indonesia. Newspapers are seen as reading belonging to fathers and fathers prefer to read newspapers without being disturbed by their children. A more common habit among parents in Indonesia is that parents read fairy tales to their children before bed. Even then, only a handful of educated and trained parents do it. Reading books together is not the culture of Indonesian parents. In fact, there are those who argue that books read by parents are not the time to be introduced to children. Scout and Atticus' habit of reading together shows evidence of constant affection and concern. This kind of affection can educate children.

\section{Quote 3:}

"Honey, wake up."

"Hurry up, honey," said Atticus. "Here are your shoes and socks." (To Kill A Mockingbird, 88)

The quote occurred when Miss Maudie Atkinson's house, Scout's neighbor caught fire. Fearing the fire spread to his home, Atticus woke his children and sent them out of the house. In that quote, there is a call 'Honey' that was made to Scout.

Among Indonesian parents, affectionate calls to children are quite common. There are those who use love calls in Indonesian, some in foreign languages. Parents in Indonesia have various ways of expressing their love for their children, including through special calls.

\section{Quote 4:}

Maybe Calpurnia felt that my day was gloomy: she let me wait for her to cook dinner. "Close your eyes and open your mouth, I have a surprise," he said.

He rarely made cornbread, he said he never had time, but since Jem and I go to school, today the workload is lighter. He knows I love cornbread.

"I missed you today," he said. "The house is so lonely, I have to turn on the radio around two o'clock."

"Why? Jem and I are never home unless it's raining."

"I know," he said, "but one of you always comes when I call. I wonder how much time I spend calling you in a day. Well, "he said, rising from the kitchen chair," enough time to make cornbread, I suppose. Come out first, I want to serve dinner."

Calpurnia bent down and kissed me. I walked out, wondering what happened to him (To Kill A Mockingbird, 33).

Scout and Jem live without a mother. Calpurnia is a chef and household assistant in their home. This scene takes place on Scout's first day of school. Calpurnia wanted to make up for Scout after he scolded the girl this afternoon. The form of affection he shows is to make Scout's favorite food and kiss him.

Providing children's favorite foods is a common practice for parents in Indonesia. Knowing what food your child likes is a sign that parents understand their child. In the case of the Finches, the character Calpurnia is not only a household assistant but also takes care of Scout and Jem. Atticus kept Calpurnia in his house so that someone would look after and accompany his two children to grow up.

It is also common for parents in Indonesia to kiss their children. It's just that hugs and kisses between adult children and their parents of the opposite sex cannot be accepted by all circles. For fanatics, a kiss between a grown child and their parents can no longer be considered as pure affection. In Indonesia, unwritten restrictions are often made regarding the form of skinship and what it is between children and parents.

\section{Quote 5:}

He unbuttoned my overalls, leaned me against his body, then pulled my shirt off. He straightened me with one hand and then reached for his pajamas with the other. 
He led me to the bed and sat me down. Lifting my feet, then covering me.

His hand raises my chin, pulls the blanket up to my neck, then tucks the edge under my body.

He turned off the light and returned to Jem's room. She'd be there all night, and she' $d$ be there when Jem woke up the next morning. (To Kill A Mockingbird, 353-354)

This scene is the end of the To Kill A Mockingbird story. At that time, Atticus had to divide his attention between Jem who was injured after being attacked by Bob Ewell and Scout who was still in shock. Atticus put Scout to sleep, then he covered Scout and waited for Jem until morning.

This form of affection is done non-verbally. The act of covering a child before bed and wearing pajamas is quite common from the perspective of parents in Indonesia. Moreover, the Eastern parenting style makes parents want to always be beside their children.

\section{Courtesy, Honesty, and Teaching in the Family Quote 6:}

"You never went to school, Atticus, and you're fine, so I want to stay home too." (To Kill A Mockingbird, 34)

Scout only addresses his father by name. He didn't insert a nickname like Dad or Daddy before calling Atticus. Atticus didn't mind the way Jem and Scout called him.

This is outside the custom of parents in Indonesia. It is considered impolite to call parents by name alone. Eastern culture highly values politeness. One of them is a respectful call given to older people. Indonesian children are accustomed to calling their parents not by name, but with honorary calls such as Father, Mother, Daddy, Mommy, Papa, Mama, Mother, Papi, Mami, Ummi, and Abi. This is different from Western culture which tends to be freer and doesn't really question vocations.

\section{Quote 7:}

You can only understand a person when you have looked at a situation from his point of view when you have entered his skin and walked around in it (To Kill A Mockingbird, 34).

Atticus taught Scout to think from another person's point of view. He taught Scouts with advice, with direct advice. This is common for parents in Indonesia. They do not hesitate to advise when the child makes a mistake.

\section{Quote 8:}

Atticus shook his head at me again. "But the food is soaked in syrup," I protested.

"Everything is poured" At that moment, Calpurnia took me to the kitchen. When she squinted at me, the little creases around her eyes deepened. "There are people who eat differently from us," he whispered fiercely, "but you can't scold them at the table because they're different. The kid is your guest, and if he wants to eat the tablecloth, you just let it go, understand?"

Calpurnia and Atticus warned Scout in different ways. Atticus just gestured for Scout to appreciate his guest. Meanwhile, Calpurnia scolded Scout fiercely so that the child would appreciate the different ways of eating his guests.

These two methods are common among Indonesian parents to their children. However, this method is not used by domestic helpers or child caregivers. The fear of being fired makes caregivers in Indonesia reluctant to reprimand their employer's children if the child makes mistakes. There are parents who reprimand in a subtle way, others give repressive actions to give punishment.

\section{Quote 9:}

Catching Walter Cunningham on the school grounds made me a little happy, but while I was rubbing his nose on the ground, Jem came over and told me to stop. "You're bigger than him," he said (To Kill A Mockingbird, 26).

Jem prevented his younger brother from attacking the younger child. In addition, Jem taught his younger brother not to vent resentment with violence. Brothers who advise their younger siblings when they make mistakes are common in Indonesian families. Brother, who feels older and has a lot of experience, will tell his younger brother whether or not an act is moral from a moral perspective.

\section{Quote 10:}

"You can't, but they can and they just did. The older you get, the more things like this you see. The only place where anyone should ever get justice is in a courtroom, regardless of skin color in the rainbow, but hatred usually carries over 
to the jury's square. As you get older, you will see white people deceive black people every day of your life, but I will tell you something and don't forget it whenever a white person does that to a black person, whoever he is, no matter how rich he is. , or no matter how good their original family, white people are trash" (To Kill A Mockingbird, 282).

The scene took place after Tom Robinson's trial and he was found guilty. Atticus was teaching his two children about the racial discrimination that occurred at that time. He did not make a speech, nor did he give angry and fiery advice. Atticus' manner of conveying the dialogue was very calm. It was that calm that sank into Scout and Jem's hearts. Atticus was honest with his two children about the big case he was facing. He also allowed his children to follow the proceedings. Since childhood, Atticus has instilled equality in Scout and Jem.

This is often missed by parents in Indonesia. When their children become critical and ask questions about injustice, parents in Indonesia tend to be silent. They prefer to hide the situation and hold back the answer until the child is an adult. Others never explain at all to satisfy children's curiosity. It is precisely at the age of children that life lessons about equality are very good to be cultivated. Children are excellent imitators. Their memory properly stores each score they get. Parents in Indonesia rarely take advantage of this opportunity to equip their children with the values of tolerance and pluralism.

\section{Conclusion}

The novel To Kill A Mockingbird is a good book for Indonesian families to read. Even though there are some values that are considered unusual in Indonesia, this book is in line with the humanistic theory of humanizing humans. This book deserves to be a compulsory reading for Indonesian children because it contains a philosophy of equality and pluralism, something that is rarely studied directly in school. So far, the concept of equality and pluralism tolerance has only been taught contextually in Pancasila Education. Meanwhile, children have not been given accurate examples in everyday life regarding the context of justice and equality regardless of ethnicity and beliefs. If this reading material is interpreted from a humanistic and hermeneutic approach, we will find values that are often overlooked by Indonesian families: the value of honesty to explain the real situation to children, and the value of equality in everyday life, not limited to concepts.

\section{Bibliography}

Lee, Harper. (2006). To Kill A Mockingbird . Bandung: Qanita

De Man, Paul. (2105). Hermeneutics. 9 November. http://plato.stanford.edu/entries/hermeneutics/. Accessed on 20 September 2020.

Sauri, Sofyan. (2020). Contextualization of Values in Life August 31 2009. http: // http://sofyansauri.lecturer.upi.edu/ kontekstualisasi-nilai-dalam-kehidup/ accessed on 20 September.

Sauri, Sofyan. (2018). Character Education in Islamic Perspective. Bandung: Rizqi Press.

Sauri, Sofyan. (2020). Learning Strategy for General Education / Values in Schools 2 September 2009 http: // http:// sofyansauri.lecturer.upi.edu/strategi-pembelajaran-pend Pendidikan-umum-nilai-disekolahan /. Accessed on 20 September 2020.

Silverman, Hugh J. (1991). Gadam er and Hermeneutics. New York: Routledge Publishing.

Norita, Ostin (2018). Character analysis of the main character in Harper Lee's novel To Kill a Mockingbird. Bachelor thesis, Stkip PGRI West Sumatra.

Monica, Sella. (2019). Moral value in novel to kill a mockingbird works harper lee as a character education alternative. https://jurnal.umj.ac.id/index.php/SEMNASFIP/indexOctober 2019 Edition.

Cite this article as: Latifah M aurinta Wigati and H. Sofyan Sauri (2021). The value of family education in novel To Kill a M ockingbird: A hermeneutic study. International J ournal of Languages and Culture. 1(2), 8-13. doi:10.51483/ IJLC.1.2.2021.8-13. 